\title{
SPATIO-TEMPORAL DYNAMICS ALONG THE TERRAIN GRADIENT OF DIVERSE LANDSCAPE
}

\author{
T. V. Ramachandra ${ }^{\mathrm{a}, \mathrm{b}, \mathrm{c}}$, Settur Bharath ${ }^{\mathrm{c}}$, Aithal Bharath ${ }^{\mathrm{b}, \mathrm{c}}$ \\ ${ }^{a}$ Energy \& Wetlands Research Group, Center for Ecological Sciences [CES], Indian Institute of Science, \\ 560012 Bangalore, India \\ ${ }^{b}$ Centre for Sustainable Technologies (astra), Indian Institute of Science, 560012 Bangalore, India \\ ${ }^{c}$ Centre for Infrastructure, Sustainable Transportation and Urban Planning [CiSTUP], \\ Indian Institute of Science, Bangalore, 560012 Karnataka, India
}

Submitted 21 July 2012; accepted 15 May 2013

\begin{abstract}
Land use (LU) land cover (LC) information at a temporal scale illustrates the physical coverage of the Earth's terrestrial surface according to its use and provides the intricate information for effective planning and management activities. LULC changes are stated as local and location specific, collectively they act as drivers of global environmental changes. Understanding and predicting the impact of LULC change processes requires long term historical restorations and projecting into the future of land cover changes at regional to global scales. The present study aims at quantifying spatio temporal landscape dynamics along the gradient of varying terrains presented in the landscape by multi-data approach (MDA). MDA incorporates multi temporal satellite imagery with demographic data and other additional relevant data sets. The gradient covers three different types of topographic features, planes; hilly terrain and coastal region to account the significant role of elevation in land cover change. The seasonality is another aspect to be considered in the vegetation dominated landscapes; variations are accounted using multi seasonal data. Spatial patterns of the various patches are identified and analysed using landscape metrics to understand the forest fragmentation. The prediction of likely changes in 2020 through scenario analysis has been done to account for the changes, considering the present growth rates and due to the proposed developmental projects. This work summarizes recent estimates on changes in cropland, agricultural intensification, deforestation, pasture expansion, and urbanization as the causal factors for LULC change.
\end{abstract}

Keywords: land use land cover (LULC), environmental impact assessment, spatial analysis, remote sensing, landscape metrics, fragmentation, terrain gradient, simulation.

Reference to this paper should be made as follows: Ramachandra, T. V.; Bharath, S.; Bharath, A. 2014. Spatio-temporal dynamics along the terrain gradient of diverse landscape, Journal of Environmental Engineering and Landscape Management 22(1): 50-63. http://dx.doi.org/10.3846/16486897.2013.808639

\section{Introduction}

Land use land cover (LULC) information of a region depicts the status of a landscape for environmental progression and sustainable development. Land cover configuration is stated as a unified reflection of the existing natural resources, dynamic natural processes whereas land use refers to the human induced changes in the land cover. LULC changes alter the homogeneous landscape into heterogeneous patches by natural processes or anthropogenic processes (Mertens et al. 2000). Landscape fragmentation is an anthropogenic process involving breaking up a continuous habitat, land use type, biota or ecosystem (Carvalho et al. 2009), which is likely to have adverse effects. Land-use/cover changes also determine the vulnerability of places and people to climatic, economic, or sociopolitical perturbations. When aggregated globally, LULC changes significantly affect central aspects of earth system functioning (Lambin et al. 2003). These changes manifest in forest fragmentation resulting in habitat loss (Mertens et al. 2000; Nagendra et al. 2004; Mingshi et al. 2011). Human induced land use changes for agricultural expansions, etc. have caused large scale deforestation leading to soil erosion, watershed

Corresponding author: T. V. Ramachandra

E-mail: cestvr@ces.iisc.ernet.in 
degradation, reduced biodiversity, and agrochemical pollution (World Bank 2008), an increase in impervious surface area and landscape fragmentations. In forest dominated landscapes fragmentation issues of prominence seem to relate typically to deforestation and loss of forest cover over a period of time. It has become an essential to integrate the patterns of land cover change with the processes of land use change by identifying various drivers of the changes. LULC change detection relies on an accurate interpretation of baseline conditions and changes in structure properties. This necessitates LULC analysis integrating landscape ecology theory and practice with other landscape science techniques. Availability of multiresolution temporal remote sensing (RS) data has aided in monitoring larger areas at various spatial, spectral and temporal resolutions. Remote sensing data along with GIS (Geographical Information Systems), GPS (Global positioning system) and other collateral data (spatial as well as statistical) help in effective LULC analysis (Ramachandra, Kumar 2004). Inventorying, mapping, quantifying, and monitoring the physical characteristics of LULC has been widely recognized as a key element in the study of regional and global changes. The strong linkages between spatial pattern and ecological process have been established (Gustafson 1998). Currently the approaches to explore spatio temporal process of LULC have been vastly improved by incorporating drivers of change (agent based modelling) and numerous methods with the help of remote sensing (Liu et al. 2010). These techniques emphasise the integrated analyses of remote sensing with socio political economic parameters for better insights to the human dimensions of LULC. Yang et al. (2011) derives the relation of population to environmental changes; by incorporating population distribution data for deriving human pressure on the surrounding environment. Social data, time series remote sensing data, and thematic coverages maintained within a GIS are integrated essentially to provide historically transformation of land conversions associated with the cultivation and other development activities in a certain landscape. Generally, gradients are widely used in landscape science and ecology to describe spatial land use patterns (Hahs, McDonnell 2006) and ecosystem structure, functions in rural-urban regions (McDonald 2009). The gradient based studies efficiently capture the large-scale changes of spatiotemporal characteristics and interactions of a landscape (Li et al. 2010).

Forest physiology is dependent on the photosynthetic activity that plays a major role in the assessment of forest physiology necessitate the understanding seasonal variations in the vegetation dominated landscapes. Satellite remote sensing in visible and near-infrared wavelengths is sensitive to changes in photosynthetic biomass and provides a means for regional mapping and monitoring of seasonal phenology (i.e. canopy growth and senescence) and growing season length for deciduous vegetation (Zhou et al. 2001). During the high water availability period, high photosynthetic activity values are detected due to the relatively low temperature (in comparison with summer temperatures), which helps in better charecterisation of forests; and conversely, during the summer, photosynthetic activity decreases as a result of high temperature and absence of water availability. All these variables affect the state of the forest reflectivity and are reflected in the varying intensity throughout the year (Volcania et al. 2005). The remote sensing data of varying seasons sheds new insight for better understanding of the seasonal dynamics of leaf and canopy (Zhang et al. 2006; Zang, Huang 2006). Sensitivity analyses improve accuracy through better estimates of seasonal changes in canopy photosynthetic capacity by incorporating seasonal remote sensing data (Waring et al. 2010).

Landscape metrics analyses through the quantification of landscape fragmentation provide better understanding of the geometric properties of a landscape. These metrics are also known as spatial metrics describe the composition and arrangement of the various patches of land cover types. These are considered for dynamic landscape monitoring, including ongoing changes (Peng et al. 2010), assessing the impacts of management decisions and human activities (Geri et al. 2010), supporting decisions on landscape and conservation planning (Garcia et al. 2011) and to analyze landscape and habitats fragmentation (Zeng, Wu 2005). Furthermore temporal variations in the spatial metrics would reflect the aggregate or cumulative effects of different dynamic processes (Herold et al. 2005). Unplanned development leads to rapid land cover changes in the region. Road density, population, land use, and topography affect forest regrowth, which results in deforestation and forest fragmentation (Freitas et al. 2010). Rail/road connectivity increases the accessibility of remote areas, allowing logging, hunting, and deforestation for new agricultural and pasture fields (Nagendra et al. 2003). Global, regional, and national demand for agricultural products creates new land use demands that influence rates of deforestation (Onojeghuo et al. 2011). Landscape pattern and progress has been seen as indicators of the future scenario with the knowledge of temporal land use and land cover data. Combining empirical spatial analyses with scenario models will reveal important details in the process of LULC changes, for the future. Scenario analysis integrated with landscape analysis characterizes uncertainties, test possible impacts, support strategic planning for policy formulation, and uses current knowledge to assess possible future conditions. Thus, in this regard the spatial dynamic models have become an inseparable aspect of a planning system. 


\section{Objective}

The objective of the study includes:

- Quantification of spatio-temporal LULC changes in the landscape during the last four decades using multi-resolution remote sensing data;

- Assessing the pattern and process of fragmentation through landscape metrics;

- Scenario analysis to visualize the growth for year 2020 considering business as usual and development scenarios.

\section{Study area}

The study area given in Figure 1 covers a $10 \mathrm{~km}$ wide and $170 \mathrm{~km}$ long gradient that extends from Hubli to Ankola which lies between long $74^{\circ} 15^{\prime} 45.64^{\prime \prime} \mathrm{E}$ to $75^{\circ} 10^{\prime} 3.23$ ' E and lat $14^{\circ} 41^{\prime} 35.19^{\prime \prime} \mathrm{N}$ to $15^{\circ} 23^{\prime} 26.93$ ' $\mathrm{N}$ and having elevation of $23 \mathrm{~m}$ (Ankola) to $637 \mathrm{~m}$ (Hubli) connects Dharwad and Uttara Kannada districts of Karnataka state, India. The study gradient extent from the core of densely populated city Hubli (planer region) to Ankola, a narrow coastal strip bordering the Arabian sea and which is moderately populated coastal region passing through Sahyadri interior (the mountain range of Western Ghats; local name is "Arabail ghat"). The gradient analysis is considered to account the spatio temporal dynamics of the region from 1973 to 2010. The entire study area is composed of moist deciduous forest, evergreen forest, dry deciduous forest, secondary degraded forest and rich in biodiversity which forms an important corridor for the movement of elephants from Anshi-Dandeli wild life sanctuary. The Bedthi river basin (also called Gangavali), with the catchment area of $3,574 \mathrm{~km}^{2}$ originates in Dharwad district and meets Arabian Sea at Gangavali village near Ankola presented in this region. The average rainfall ranges from $720 \mathrm{~mm}$ (plane section) to $3593 \mathrm{~mm}$ (coast). The region is well connected through large motorways NH

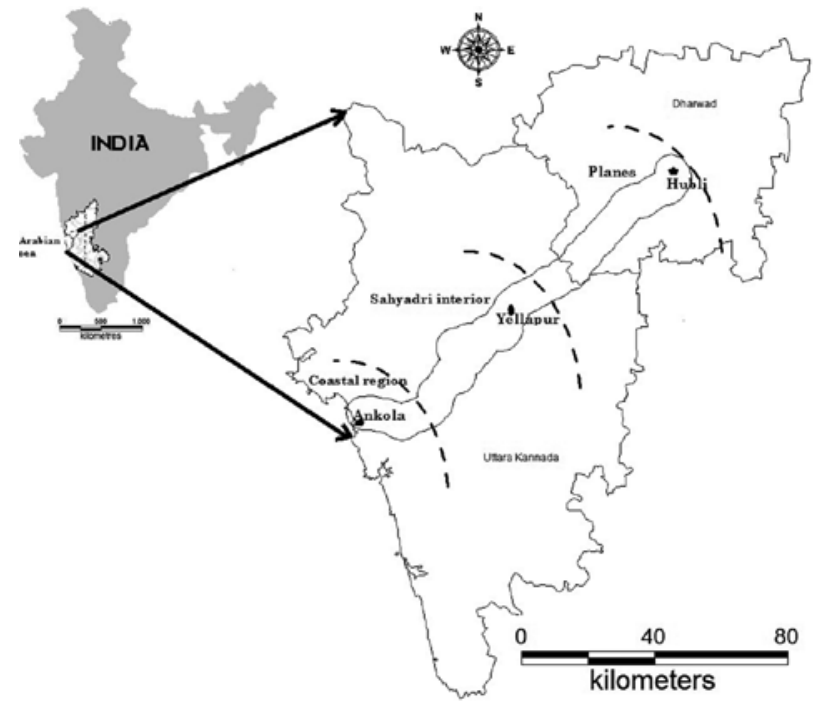

Fig 1. Study area - Hubli Ankola landscape gradient
63 (Nation High way No-63). However, the study region has also secondary roads, some paved and a large amount of unmetal roads, used mostly for local traffic and transport of agricultural products to the city or to the coast. Agriculture and native forest are the dominant land use class in this region and also some reforestation and deforestation activities have altered the spatial configurations of forest fragments.

\section{Data and method}

\subsection{Remote sensing (RS) data}

The RS data used in the study include Landsat MSS (1973), TM (1989, 2000), Landsat ETM+ (2003, 2004), IRS LISSIV MX (2009, 2010), and Google Earth (http://earth.google.com). The Landsat data is cost effective, with high spatial resolution and freely downloadable from public domains like GLCF (http://glcfapp.glcf.umd.edu:8080/esdi) index.jsp) and USGS (http://glovis.usgs.gov/). The different seasonal data (summer, post monsoon) is considered to account the adverse effect of seasonal variation in canopy light interception. The summery characteristics of datasets used in the current study are summarized in Table 1.

Table 1. Details of remote sensing data

\begin{tabular}{cccc}
\hline Year & Satellite & $\begin{array}{c}\text { Date of } \\
\text { Acquisition }\end{array}$ & $\begin{array}{c}\text { Resolution } \\
(\mathrm{m})\end{array}$ \\
\hline 1973 & Landsat MSS & $02 / 11 / 1973$ & 57 \\
1989 & Landsat TM & $19 / 11 / 1989$ & 28.5 \\
2000 & Landsat TM & $25 / 11 / 2000$ & 30 \\
2003 & Landsat TM & $01 / 02 / 2003$ & 30 \\
2004 & Landsat & $22 / 11 / 2004$ & 30 \\
\multirow{2}{*}{2010} & ETM+ & IRS P6 L4 & - \\
& MX & 5 \\
\hline
\end{tabular}

\subsection{Ancillary data}

Ancillary data provides helpful information to assist the interpretation of different land use types from remotely sensed images. Besides remote sensing data, many other data sources were used in the study. The multi-data are used to make use of different data sets available for better interpretation and to improve the accuracy of the datasets. Frequently used ancillary data are the Survey of India topographic maps at varying scales (1:50000, 1:250000). Topographic maps provided ground control points to rectify remotely sensed images and scanned historical paper maps. The population data (2001, 2011 census) collected from the directorate of census operation is used to analyse the population distribution of study area. Other ancillary data includes land cover maps, administration boundary details, transportation data (road network) and field data using GPS (Global Positioning System - Garmin GPS). 


\subsection{Method}

Figure 2 illustrates the method adopted for the analysis. RS data of different sensors of Landsat (a series of earth resource scanning satellites launched by the USA) were downloaded from the public domain (http://glovis.usgs.gov) while IRS (Indian Remote Sensing Satellites) data were procured from the National Remote Sensing Centre, Hyderabad (http://www.nrsc.gov.in). These data were preprocessed for atmospheric and geometric corrections to enable correct area measurements, precise localization and multi-source data integration (Jixian et al. 2007). The field investigation is carried out for the collection of ground control points (GCP's) and training data (with attribute data) studies during pre-monsoon and post-monsoon seasons. The geographic coordinates of a land cover classes (of the training polygons) are determined by using pre-calibrated GARMIN GPS - Global Position Systems. Historical land-cover data were compiled from the forest department records apart from the interviews and group discussions with the local farmers and forest officials. Geometric correction is implemented by using ground control points collected from field using GPS. Landsat data is resampled to 30 meters, for comparison across multi-resolution data of Landsat sensors with dissimilar spatial resolutions.

NDVI (Normalized Difference Vegetation Index) was computed with the temporal data for land cover analysis. NDVI is based on the principle of spectral difference based on strong vegetation absorbance in the red and strong reflectance in the near-infrared part of the spectrum. Vegetation index differencing technique was used to analyse the amount of change in vegetation (green) versus non-vegetation (nongreen) with the two temporal data of 1973 and 1989 as reference. Calculation of NDVI for Multi-temporal data is advantageous in areas with rapid vegetation changes. Among numerous vegetation indices for land cover mapping, NDVI is most widely accepted and applied (Ramachandra et al. 2009). NDVI is calculated using visible Red (0.63-0.69 $\mu \mathrm{m})$ and NIR $(0.76-0.90 \mu \mathrm{m})$ bands of Landsat TM/ETM+. NDVI for a given pixel ranges from minus one $(-1)$ to plus one (+1). NDVI was calculated using Eq. (1):

$$
N D V I=(N I R-R / N I R+R)
$$

The land use analysis was done using supervised classification scheme with selected training sites. Image classification pursues to categorize features on the image based on their spectral character. Gaussian Maximum Likelihood classifier (GMLC) is a common, appropriate and efficient method in supervised classification techniques by using multi-temporal "ground truth" information with the suitable training set for classifier learning.

Supervised training areas are located in regions of homogeneous land use classes: built-up, water, cropland, grass lands (degraded forest), open space or barren land,

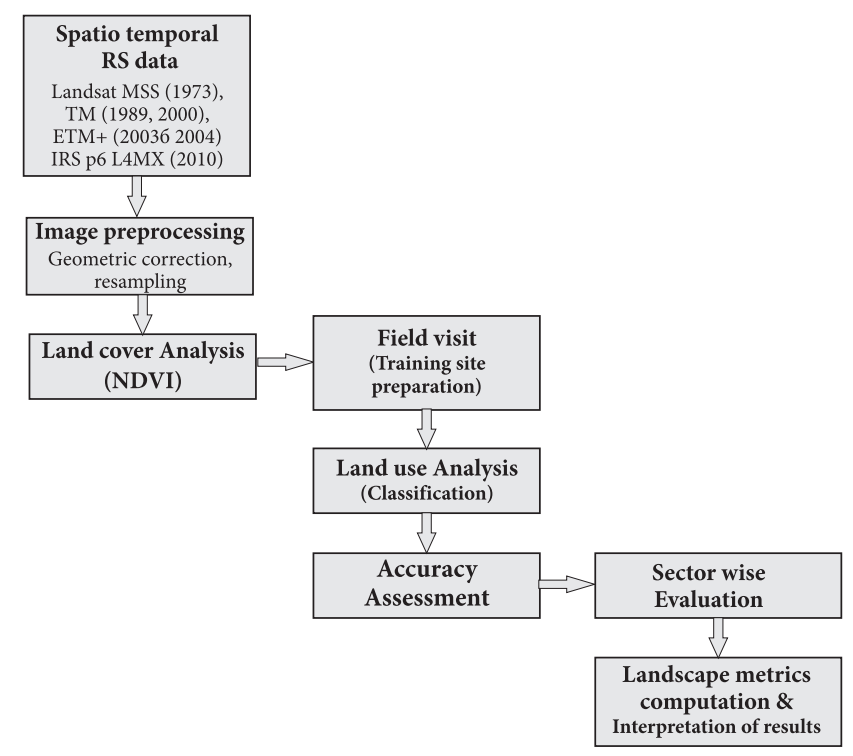

Fig. 2. Method for spatio temporal analysis using remote sensing data

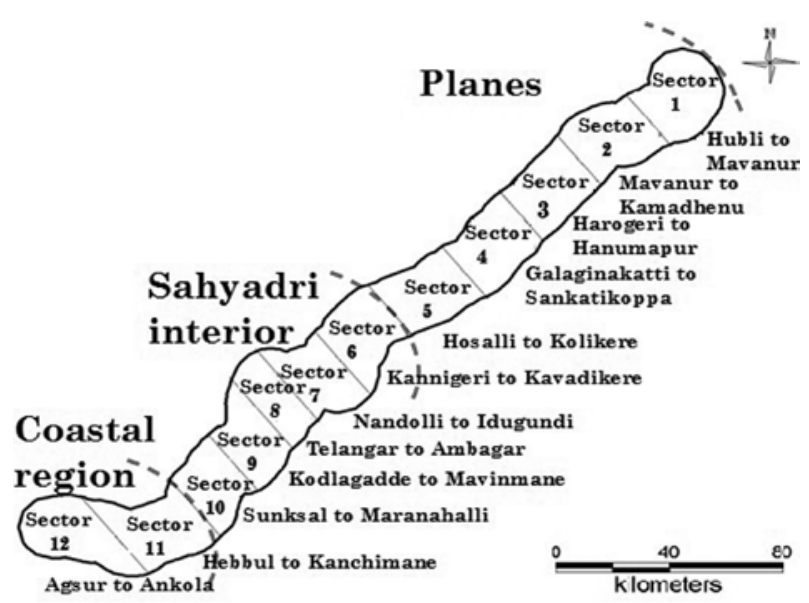

Fig. 3. Sector based divisions of study area

deciduous forest, evergreen forest. GRASS GIS (Geographical Analysis Support System, http://ces.iisc.ernet.in/ grass) a free and open source software having the robust support for processing both vector and raster files is used for LULC analysis. An accuracy assessment is done to assess the quality of the information derived from remotely sensed data by a set of reference pixels. These test samples are then used to generate the error matrix (also referred as confusion matrix) kappa ( $\kappa)$ statistics and producer's (PA) and user's accuracies (UA) to assess the classification accuracies. Kappa is an accuracy statistic that permits us to compare two or more matrices and weighs cells in error matrix according to the magnitude of misclassification. Accuracy assessment with kappa statistics has been done, which aided in evaluating the strength of each class as well as the efficacy of classification technique.

In order to access the detailed LULC pattern, a study is carried out at macro and micro scales by considering the whole landscape as a single unit and sector based 
analysis. The study area has been divided in to 12 sectors/ segments as the landscape is of varying topography with diverse land use; each sector covers around $13 \mathrm{~km}$ length as shown in Figure 3. Landscape dynamics was analysed for each sector for 1973, 1989, and 2010 through landscape metrics using FRAGSTAT 3.3 (McGarigal et al. 2002) to explain the spatial heterogeneity changes in the region. A set of significant indicators were prioritized for a detailed analysis of the landscape. Table 2 lists the chosen metrics with range and descriptions. In the regional planning, demographic aspect is one of the most significant aspects as decentralized planning would be effective. The population density is computed to understand the spatial dimensions in human settlements. Density gradient metrics computation is done using Alpha and Beta population density to investigate land transformation with respect to population in each sector. Alpha population density is the ratio of total population in a region to the total built-up area, while Beta population density is the ratio of total population to the total geographical area. These metrics have been often used as the indicators of urbanization and urban spread (Sudhira et al. 2004; Ramachandra et al. 2012) and are given by:

$$
\begin{aligned}
& \alpha \text { density }=(\text { Total Population } / \text { Total Built up Area }) ; \\
& \beta \text { density }=(\text { Total Population } / \text { Total Geographic Area }) .
\end{aligned}
$$

Prediction of likely changes has been done through scenario analysis, using LULC change as an input. The model generated possible scenarios of land-use changes considering the current rate of LU changes and also by considering the likely developmental projects, along with various indicators like deforestation and fragmentation.

\begin{tabular}{|c|c|c|c|c|}
\hline & Indicators & Formula & Range & Significance \\
\hline 1 & $\begin{array}{l}\text { Number of Urban } \\
\text { Patches }\end{array}$ & $\begin{array}{l}N P U=n \\
\text { NP equals the number of patches in the } \\
\text { landscape. }\end{array}$ & $\begin{array}{l}N P U>0, \\
\text { without limit }\end{array}$ & $\begin{array}{l}\text { Higher the value more the } \\
\text { fragmentation. }\end{array}$ \\
\hline 2 & $\begin{array}{l}\text { Largest Patch } \\
\text { Index (Percentage } \\
\text { of built up) }\end{array}$ & $\begin{array}{l}L P I={ }_{i=1}^{n} \frac{\operatorname{Max}(a i)}{A}(100) \\
a_{i}=\operatorname{area}\left(\mathrm{m}^{2}\right) \text { of patch } i \\
A=\text { total landscape area. }\end{array}$ & $0 \leq L P I \leq 100$ & $\begin{array}{l}L P I=0 \text { when largest patch of the patch } \\
\text { type becomes increasingly smaller. } \\
L P I=100 \text { when the entire landscape } \\
\text { consists of a single patch. }\end{array}$ \\
\hline 3 & $\begin{array}{l}\text { Perimeter Area } \\
\text { Weighted Mean } \\
\text { Ratio. PARA_AM }\end{array}$ & $\begin{array}{l}P A R A_{-} A M=\frac{P_{i j}}{A_{i j}} \\
P_{i j}=\text { perimeter of patch } i j ; \\
A_{i j}=\text { area weighted mean of patch } i j . \\
A M=\sum_{J=1}^{n}\left[X i j\left[\frac{a i j}{\sum_{j=1}^{n} a i j}\right]\right]\end{array}$ & $\begin{array}{l}>0, \text { without } \\
\text { limit }\end{array}$ & $\begin{array}{l}\text { PARA AM is a very useful measure of } \\
\text { fragmentation; it is a measure of the } \\
\text { amount of 'edge' for a landscape or } \\
\text { class. PARA } A M \text { value increased with } \\
\text { increasing patch shape complexity, } \\
\text { which characterize the degree of patch } \\
\text { shape complexity. }\end{array}$ \\
\hline 4 & $\begin{array}{l}\text { Area Weighted } \\
\text { Mean Shape } \\
\text { Index }(A W M S I)\end{array}$ & $\begin{array}{l}A W M S I=\frac{\sum_{i=1}^{i=N} P_{i} / \sqrt[4]{S_{i}}}{N} \times \frac{S_{i}}{\sum_{i=1}^{i=N} S_{i}} \\
\text { where } S_{i} \text { and } P_{i} \text { are the area and perimeter of } \\
\text { patch } i \text {, and } N \text { is the total number of patches. }\end{array}$ & $\begin{array}{l}A W M S I \geq 1 \\
\text { without limit }\end{array}$ & $\begin{array}{l}A W M S I=0 \text { when all patches in the } \\
\text { landscape are circular or square. } \\
A W M S I \text { increases without limit as the } \\
\text { patch shape becomes irregular. This } \\
\text { index represents the shape irregularity } \\
\text { of patches. The higher this value is, the } \\
\text { more irregular the shapes are. }\end{array}$ \\
\hline 5 & $\begin{array}{l}\text { Area weighted } \\
\text { Euclidean mean } \\
\text { nearest neighbor } \\
\text { distance } E N N \_A M\end{array}$ & $\begin{array}{l}E N N=h_{i j} \\
h_{i j} \text { is distance }(\mathrm{m}) \text { from patch ij to nearest } \\
\text { neighboring patch of the same type(class) } \\
\text { based on shortest edge to edge distance. }\end{array}$ & $\begin{array}{l}E N N>0, \\
\text { without limit }\end{array}$ & $\begin{array}{l}E N N \text { approaches zero as the distance } \\
\text { to the nearest neighbor decreases. } \\
E N N \_A M \text { is used to calculate relative } \\
\text { distance between the patches of same } \\
\text { class. }\end{array}$ \\
\hline 6 & $\begin{array}{l}\text { Shannon's } \\
\text { diversity index }\end{array}$ & $\begin{array}{l}S H=-\sum_{i=1}^{m} p i \cdot \ln (p i) \\
i-\text { patch type; } \\
m-\text { number of patch type; } \\
p i-\text { proportion of the landscape occupied by } \\
\text { patch type } i \text {. }\end{array}$ & $\begin{array}{l}\text { Range: } \\
S H D I \geq 0, \\
\text { without limit }\end{array}$ & $\begin{array}{l}\text { Shannon's diversity index is a measure } \\
\text { of diversity. SHDI increases as the } \\
\text { number of different patch types } \\
\text { (patch richness, PR) increases or the } \\
\text { proportional distribution of area among } \\
\text { patch types becomes more equitable, } \\
\text { or both. }\end{array}$ \\
\hline
\end{tabular}

Table 2. Landscape metrics selected in the study 
The spatial dynamic models have become an inseparable aspect of a planning system in this regard, model has been implemented using NetLogo (Wilensky 1999), an agent-based modelling environment developed by the Centre for Connected Learning and Computer Based Modeling, Northwestern University, USA, which facilitates encapsulation of processes through rule-based procedures and offers adequate monitors and plots to visualise pattern, model the causes and evaluate the consequences through simulation.

\section{Results}

Land Cover Analysis: Figure 4 illustrates the spatio temporal changes in the land cover, done by computing NDVI Table 3 explains the land cover changes, which show vegetation cover of $98.78 \%$ (1973) has decreased to $83.14 \%$ in 2010. Seasonal variation is evident in NDVI values of 2003 and 2004. Even though drastic land cover changes were observed during 1973 to 1989 , the changes during 1989 to 2010 are relatively lower. In order to account these changes, we have considered 1973 and 1989 as base years. The rate of changes from 1973 to 1989 is $7.04 \%$ whereas 1989 to 2000 is $1.93 \%$. These could be due to the forest conservation measures due to the ban on logging with the implementation of the Indian Forest ACT 1978 by the Karnataka forest department. The decline of vegetation during 1973 to 2010 is $15.64 \%$.

Table 3. Land cover analysis from 1973 to 2010

\begin{tabular}{|c|c|c|c|c|}
\hline \multirow[b]{2}{*}{ Year } & \multirow[b]{2}{*}{$\begin{array}{l}\text { Vege- } \\
\text { tation, \% }\end{array}$} & \multirow{2}{*}{$\begin{array}{c}\text { Non- } \\
\text { vegetation, } \\
\%\end{array}$} & \multicolumn{2}{|c|}{ Temporal change } \\
\hline & & & $\begin{array}{c}1973 \text { as } \\
\text { base year }\end{array}$ & $\begin{array}{c}1989 \text { as } \\
\text { base year }\end{array}$ \\
\hline 1973 & 98.78 & 1.22 & - & - \\
\hline 1989 & 91.74 & 8.26 & -7.04 & - \\
\hline 2000 & 89.81 & 10.19 & -8.97 & -1.93 \\
\hline 2003 & 86.95 & 13.05 & -11.83 & -4.79 \\
\hline 2004 & 88.38 & 11.62 & -10.4 & -3.36 \\
\hline 2010 & 83.14 & 16.86 & -15.64 & -8.6 \\
\hline
\end{tabular}

Land Use Analysis: The spatio temporal land use changes during 1973 to 2010 are given in the Figure 5 and Table 4. The urban land is increased from $0.18 \%$ (1973) to $0.81 \%(2010)$, the area of deciduous forest is decreased from $56.23 \%$ (1973) to $47.93 \%$ (2010), and the area of evergreen forest remains same due to the forest regeneration and implementation of forest policies whereas agricultural land has increased from $25.55 \%$ to $30.31 \%$. This illustrates the influence of human induced agricultural activities are major driving forces of the changes in forest cover in the region.

The seasonality is one of major influential factors in the forest based landscape study. To account the seasonal variation in the vegetation cover the multi-season remote sensing data is considered, i.e. 2003 (pre-monsoon) and

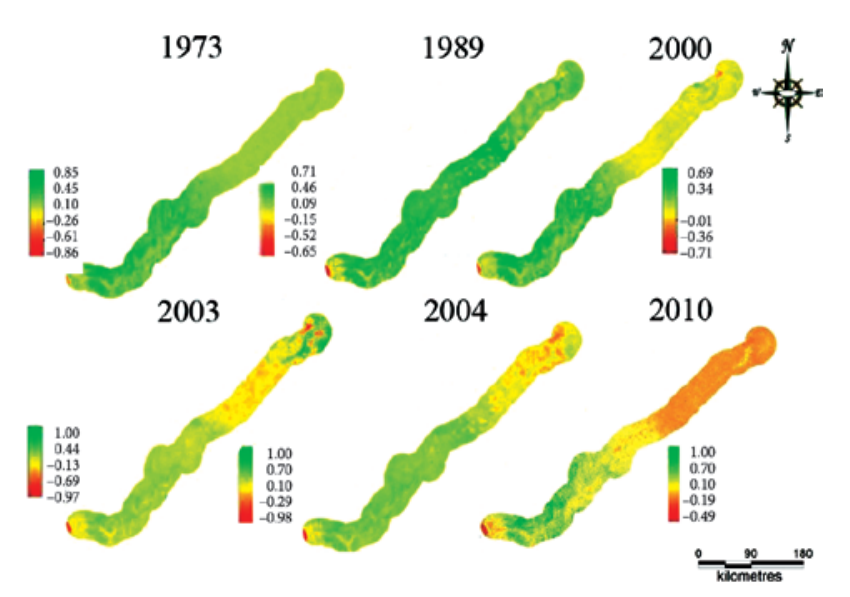

Fig. 4. Land cover analysis through NDVI
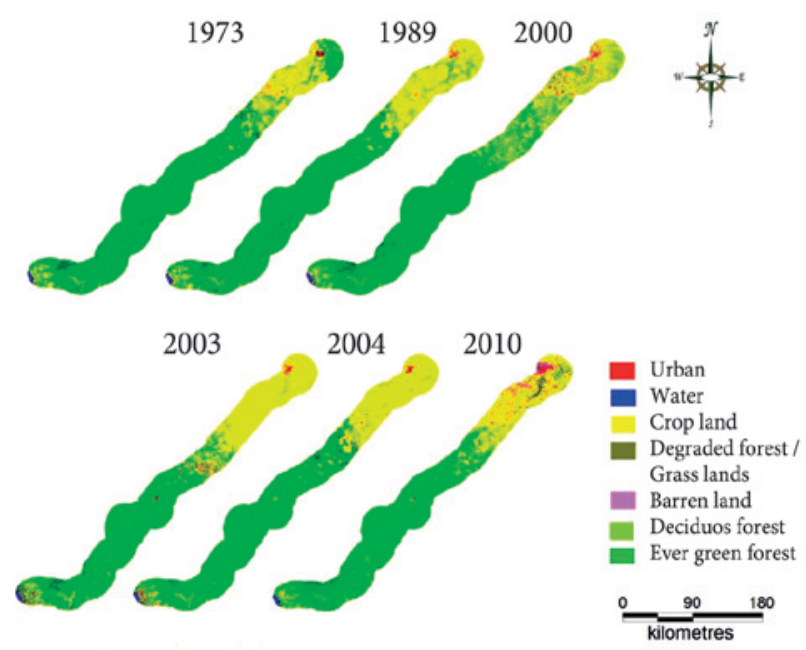

Fig. 5. Land use analysis

Table 4. Spatio temporal land use dynamics

\begin{tabular}{lcccccc}
\hline Year & \multicolumn{2}{c}{1973} & \multicolumn{2}{c}{1989} & \multicolumn{2}{c}{2000} \\
\hline Category & $\mathrm{Ha}$ & $\%$ & $\mathrm{Ha}$ & $\%$ & $\mathrm{Ha}$ & $\%$ \\
\hline Urban & 266.46 & 0.18 & 502.87 & 0.35 & 769.61 & 0.53 \\
\hline Water & 698.67 & 0.48 & 661.62 & 0.46 & 833.5 & 0.58 \\
\hline $\begin{array}{l}\text { Crop } \\
\text { land }\end{array}$ & 36965.48 & 25.55 & 45796.59 & 31.65 & 50447.44 & 34.86 \\
\hline $\begin{array}{l}\text { Deci- } \\
\text { duous } \\
\text { forest }\end{array}$ & 81366.53 & 56.23 & 76157.34 & 52.62 & 73522.03 & 50.81 \\
\hline $\begin{array}{l}\text { Ever- } \\
\text { green } \\
\text { forest }\end{array}$ & 13249.41 & 9.16 & 13242.42 & 9.15 & 9872.05 & 6.82 \\
$\begin{array}{l}\text { Degra- } \\
\text { ded } \\
\text { forest }\end{array}$ & 8690.14 & 6 & 6086.11 & 4.21 & 5275.02 & 3.65 \\
$\begin{array}{l}\text { Barren } \\
\text { land }\end{array}$ & 3465.44 & 2.4 & 2255.18 & 1.56 & 3982.48 & 2.75 \\
\hline
\end{tabular}


Continued Table 4

\begin{tabular}{lcccccc}
\hline Year & \multicolumn{2}{c}{2003} & \multicolumn{2}{c}{2004} & \multicolumn{2}{c}{2010} \\
\hline Category & Ha & $\%$ & Ha & $\%$ & Ha & $\%$ \\
\hline Urban & 916.21 & 0.63 & 931.16 & 0.64 & 1169.82 & 0.81 \\
\hline Water & 800.65 & 0.55 & 510.09 & 0.35 & 835.84 & 0.58 \\
\hline $\begin{array}{l}\text { Crop } \\
\text { land }\end{array}$ & 52198.60 & 36.07 & 49303.58 & 33.98 & 43856.97 & 30.31 \\
\hline $\begin{array}{l}\text { Deci- } \\
\text { duous } \\
\text { forest }\end{array}$ & 67018.23 & 46.31 & 71611.1 & 48.86 & 69355.54 & 47.93 \\
\hline $\begin{array}{l}\text { Ever- } \\
\text { green } \\
\text { forest }\end{array}$ & 9128.59 & 6.32 & 10116.74 & 6.97 & 12709.93 & 8.78 \\
\hline $\begin{array}{l}\text { Degra- } \\
\text { ded } \\
\text { forest }\end{array}$ & 8460.63 & 5.85 & 9900.46 & 7.09 & 8949.23 & 6.18 \\
$\begin{array}{l}\text { Barren } \\
\text { land }\end{array}$ & 6179.21 & 4.27 & 2329.00 & 2.11 & 7824.8 & 5.41 \\
\hline
\end{tabular}

2004 (post monsoon) as deciduous species shed their leaves in the pre monsoon period, which lead to the change in the reflection of vegetation in remote sensing data and it is accounted as a cropland. Further Google Earth (http://www.googleearth.com) is used to verify the data and to quantify the areas by digitising polygons from land cover map. The result shows around 3\% area of dry deciduous forest is accounted as croplands.
The land use classification of temporal remote sensing data is verified with training samples which are randomly chosen for assessment. The producer accuracy computed for each category listed in Table 5, provides the probability that an area on the ground that was identified as a particular suitability type on the classified map. User accuracy is the probability that a point on the map classified as a particular suitability category will actually be that category on the ground. KHAT (KAPPA statistic) summarizes overall results and measures difference between the actual agreements in the error matrix which is ranging from $87 \%$ to $94 \%$.

Sector-wise Land use Analysis: In order to access the land use at micro scale sector wise land use assessment is done by using 2010 IRS data (finer spatial resolution of $5.8 \mathrm{~m}$ ). The sector-wise land use pattern is depicted in Figure 7.

Sector 1 to 6 covers the plane section of the region; sector 6 to 10 covers the Sahyadri mountains/Ghats section and sector 11, 12 covers the coastal region. Figure 6 shows the population density in the region, which explains the human distribution in the villages, covered in gradient. Table 6 lists sector-wise land use while Table 7 lists sector-wise population with Alpha, Beta population densities.

Sector 1 covers the Hubli region with the dominant land use as cropland of $61.73 \%, 4.25 \%$ built-up area and higher population of 8, 21,906 and $\alpha$ Density (1384.23);

Table 5a. Accuracy assessment (PA - Producer's Accuracy, UA - User's Accuracy)

\begin{tabular}{|c|c|c|c|c|c|c|c|c|c|c|c|c|}
\hline \multirow{2}{*}{ Category } & \multicolumn{2}{|c|}{1973} & \multicolumn{2}{|c|}{1989} & \multicolumn{2}{|c|}{2000} & \multicolumn{2}{|c|}{2003} & \multicolumn{2}{|c|}{2004} & \multicolumn{2}{|c|}{2010} \\
\hline & PA & UA & $\mathrm{PA}$ & UA & PA & UA & PA & UA & PA & UA & PA & UA \\
\hline Urban & 99.01 & 100.00 & 62.69 & 40.83 & 55.04 & 93.02 & 53.35 & 99.38 & 78.23 & 93.02 & 89.18 & 100.00 \\
\hline Water & 99.70 & 88.26 & 99.99 & 99.86 & 99.31 & 79.49 & 99.75 & 99.42 & 98.98 & 79.49 & 91.42 & 92.44 \\
\hline Cropland & 98.09 & 80.05 & 79.60 & 97.29 & 86.50 & 93.84 & 96.65 & 89.52 & 99.47 & 93.84 & 97.58 & 98.46 \\
\hline Degraded forest & 60.16 & 55.44 & 94.58 & 75.65 & 96.28 & 76.45 & 52.70 & 98.82 & 39.50 & 76.45 & 86.05 & 84.64 \\
\hline Barren land & 61.77 & 92.21 & 44.19 & 39.36 & 93.39 & 62.50 & 61.31 & 99.45 & 71.31 & 62.50 & 99.93 & 96.96 \\
\hline Deciduous forest & 88.53 & 96.13 & 98.88 & 90.61 & 95.59 & 94.63 & 99.93 & 95.55 & 98.72 & 94.63 & 86.49 & 95.26 \\
\hline Evergreen forest & 92.29 & 98.62 & 94.78 & 100.00 & 99.71 & 100.00 & 99.99 & 100.00 & 99.84 & 100.00 & 97.86 & 81.39 \\
\hline
\end{tabular}

Table 5b. Overall accuracy and Kappa

\begin{tabular}{ccc}
\hline Year & Overall Accuracy & Kappa value \\
\hline 1973 & 87.38 & 0.81 \\
1989 & 91.24 & 0.85 \\
2000 & 92.47 & 0.87 \\
2003 & 93.51 & 0.89 \\
2004 & 94.42 & 0.90 \\
2010 & 93.01 & 0.90 \\
\hline
\end{tabular}

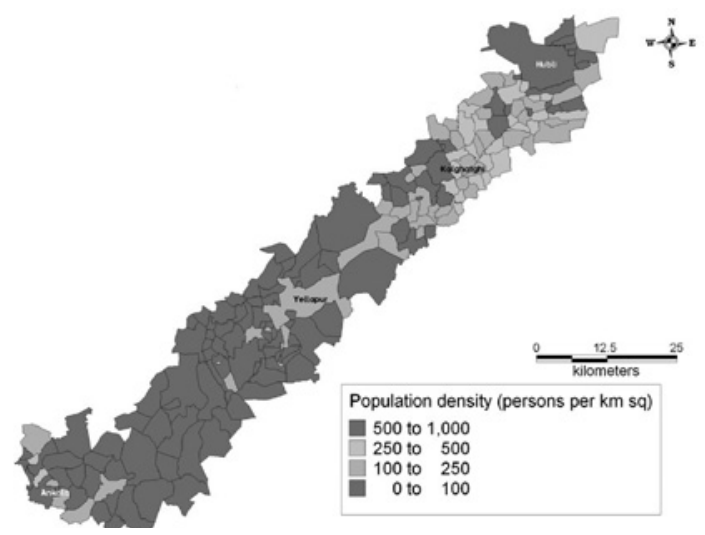

Fig. 6. Population density in the gradient 
$\beta$ Density (55.854) values, which explains the intense urbanisation. Cropland (70.29\%) continues to be dominant land use in Sector 2 along with barren lands. This sector has the population of 42,463 .

Sector 3 is dominated by cropland $(83.24 \%)$ with a smaller amount of dry deciduous forest cover $(2.66 \%)$. Population in sector 3 is 50,733 with $\alpha$ Density of 368.1 and $\beta$ Density of 4.09 . Sector 4 has $54 \%$ of cropland, $42 \%$ of deciduous forest and population of 12,447.
Sector 5 is mostly dominated by deciduous forest cover $(79.17 \%)$ with the Density of 8229.73 and lower $\beta$ Density (0.976).

Sector 6 has $78.64 \%$ of moist deciduous forest cover with the moderate $\alpha$ Density (24359) being the part of Yellapur town (24359).

Sector 7 rich in biodiversity is dominated by moist deciduous forest $(78.52 \%)$ with small fraction of evergreen $(5.06 \%)$ and human population of 7517 . Sector

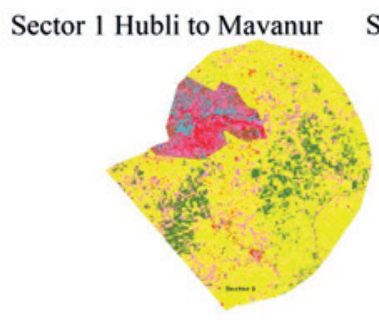

\section{Sector}
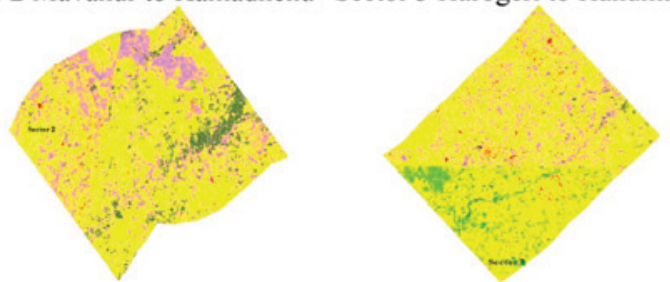

Sector 5 Hosalli to Kolikere
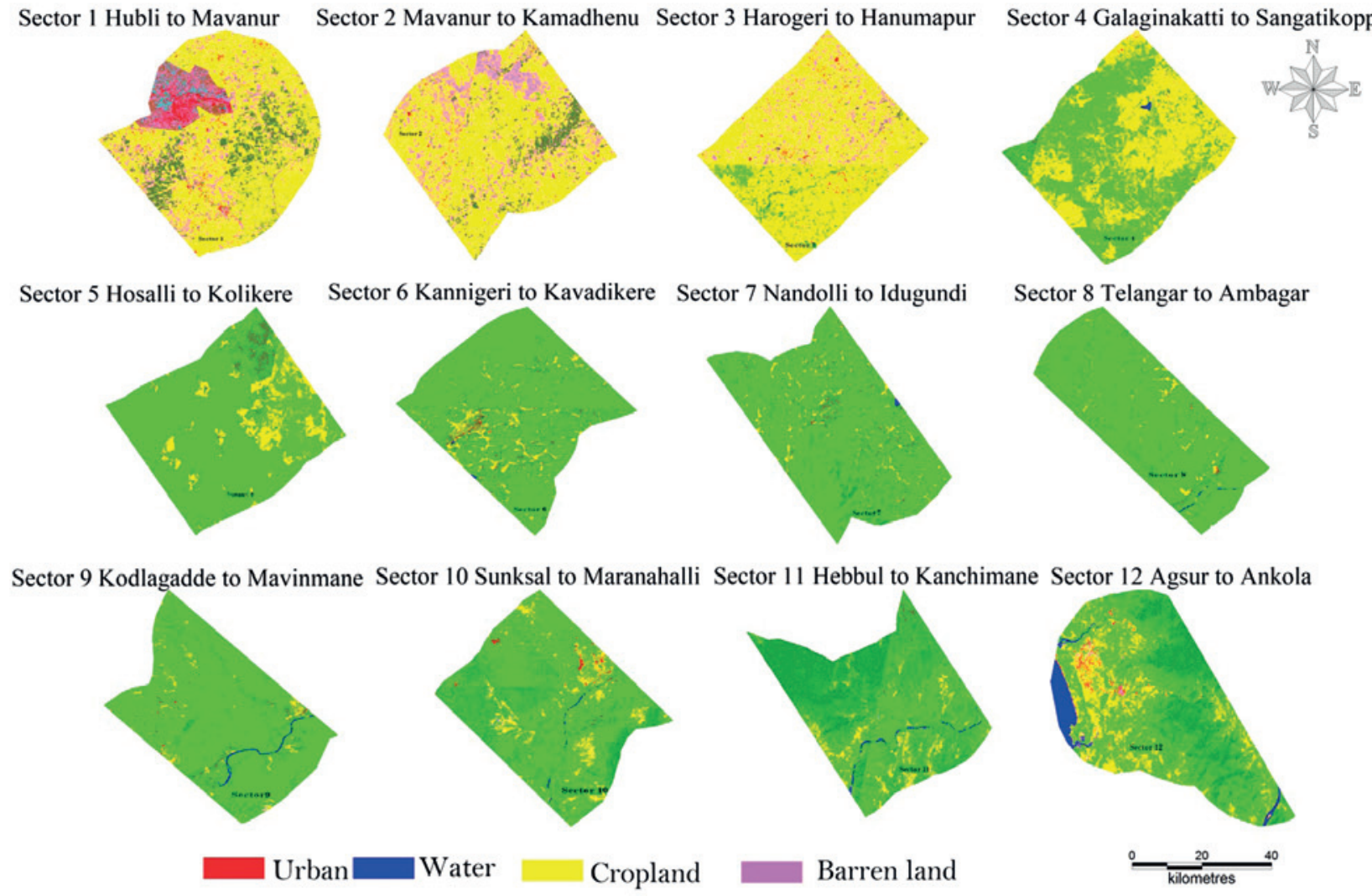

Sector 8 Telangar to Ambagar

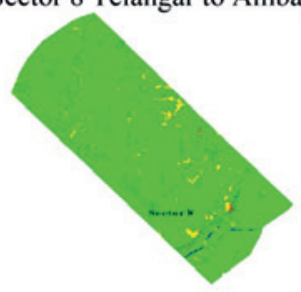

Degraded forest/ Grass alnds

Deciduous forest

Ever green forest

Fig. 7. Sector-wise land use dynamics

Table 6. Land use statistics of sector 1 to 12

\begin{tabular}{|c|c|c|c|c|c|c|c|c|c|c|c|c|c|c|}
\hline \multirow{2}{*}{$\begin{array}{r}\text { Cate- } \\
\text { gory }\end{array}$} & \multicolumn{2}{|c|}{ Urban } & \multicolumn{2}{|c|}{ Water } & \multicolumn{2}{|c|}{ Cropland } & \multicolumn{2}{|c|}{ Degraded forest } & \multicolumn{2}{|c|}{ Barren land } & \multicolumn{4}{|c|}{ Deciduous forest Evergreen forest } \\
\hline & Ha & $\%$ & $\mathrm{Ha}$ & $\%$ & $\mathrm{Ha}$ & $\%$ & $\mathrm{Ha}$ & $\%$ & $\mathrm{Ha}$ & $\%$ & $\mathrm{Ha}$ & $\%$ & $\mathrm{Ha}$ & $\%$ \\
\hline $\mathrm{S} 1$ & 593.8 & 4.3 & 0.58 & 0 & 8620.1 & 61.73 & 1700.3 & 12.2 & 3050.5 & 21.8 & 0.0 & 0 & 0.0 & 0 \\
\hline S2 & 76.8 & 0.6 & 0.02 & 0 & 9015.2 & 70.3 & 840.8 & 6.6 & 2892.4 & 22.6 & 0.0 & 0 & 0.0 & 0 \\
\hline S3 & 137.8 & 1.1 & 1.6 & 0.0 & 10329.1 & 83.3 & 249.6 & 2.0 & 1347.4 & 10.9 & 0.0 & 0 & 0.0 & 0 \\
\hline S4 & 33.3 & 0.3 & 19.1 & 0.2 & 5406.6 & 42.6 & 292.4 & 2.3 & 5.0 & 0.1 & 5406.6 & 42.6 & 0.0 & 0 \\
\hline S5 & 1.5 & 0.0 & 1.0 & 0.0 & 1674.8 & 13.3 & 952.8 & 7.5 & 0.0 & 0.0 & 9993.8 & 79.2 & 0.0 & 0 \\
\hline S6 & 20.8 & 0.2 & 11.1 & 0.1 & 900.9 & 7.4 & 1677.0 & 13.8 & 0.1 & 0.0 & 9520.9 & 78.4 & 8.5 & 0.1 \\
\hline S7 & 2.3 & 0.0 & 12.1 & 0.1 & 601.5 & 5.4 & 1225.5 & 10.9 & 0.1 & 0.0 & 8806.2 & 78.5 & 567.2 & 5.1 \\
\hline S8 & 5.6 & 0.1 & 19.9 & 0.2 & 291.0 & 3.4 & 370.5 & 4.3 & 0.0 & 0.0 & 7556.8 & 88.0 & 339.9 & 4.0 \\
\hline S9 & 42.0 & 0.4 & 69.7 & 0.7 & 445.6 & 4.3 & 578.5 & 5.6 & 21.9 & 0.2 & 8830.3 & 85.1 & 392.6 & 3.8 \\
\hline S10 & 69.4 & 0.7 & 25.0 & 0.2 & 978.2 & 9.6 & 350.7 & 3.4 & 158.3 & 1.6 & 6773.7 & 66.3 & 1864.5 & 18.2 \\
\hline S11 & 5.6 & 0.0 & 88.7 & 0.6 & 1029.0 & 7.4 & 383.8 & 2.8 & 223.9 & 1.6 & 6088.5 & 43.6 & 6146.9 & 44.0 \\
\hline $\mathrm{S} 12$ & 181.0 & 1.3 & 587.1 & 4.3 & 3034.2 & 22.2 & 327.4 & 2.4 & 125.1 & 0.9 & 6050.9 & 44.2 & 3390.5 & 24.8 \\
\hline
\end{tabular}


Table 7. Sector-wise distribution of population and $\alpha, \beta$ densities

\begin{tabular}{cccc}
\hline Sectors & $\begin{array}{c}\text { Total } \\
\text { Population }\end{array}$ & $\alpha$ Density & $\beta$ Density \\
\hline S1 & 821906 & 1384.22 & 58.85 \\
S2 & 42463 & 552.64 & 3.31 \\
S3 & 50733 & 368.16 & 4.09 \\
S4 & 12447 & 373.76 & 0.98 \\
S5 & 12320 & 8229.79 & 0.98 \\
S6 & 24359 & 1171.95 & 2.01 \\
S7 & 7517 & 3282.53 & 0.67 \\
S8 & 4789 & 855.57 & 0.56 \\
S9 & 7081 & 168.41 & 0.68 \\
S10 & 2368 & 34.14 & 0.23 \\
S11 & 5956 & 1070.26 & 0.43 \\
S12 & 59288 & 327.55 & 4.33 \\
\hline
\end{tabular}

8 covers moist deciduous forest (88.04\%), evergreen (3.86\%) and human population of 4789 .

Sector 9 has dominant deciduous forest $(85.06 \%)$ with evergreen forest $(3.78 \%)$. Similar situation prevails in Sector 10 with deciduous $(66.28 \%)$ and evergreen $(18.24 \%)$ forests. This sector has sparse human population (2368) compared to all other sectors. Sector 11 has equal proportion of deciduous $(43.59 \%)$ and semi evergreen $(44.01 \%)$ forests. Sector 12 covers part of Ankola town and its suburbs and consists of deciduous forest (44.18\%), semi evergreen $(24.75 \%)$ with the population of 59288 .

\section{Spatial metrics}

The spatial metrics for the year 1973, 1989, and 2010 gives the landscape status in terms of heterogeneity, diversity, etc. for each sector. Figures 8 (a) to (f) depict sectorwise metrics across three time periods.

Sector 1 with dense population shows large number of patches, which explains the fragmentation of region. 11 patches in vegetation category (1973) has increased to 4118 (2010), illustrates of receding of vegetation and major green patches are becoming more number of patches, due to the fragmentation. LPI shows that largest patch is the cropland (68.34\%) in this sector among all other land use classes. PARA_AM shows highest value for urban class, which explains the shape complexity of the region because of urban spread in the region and also each land use category is showing increase in the value from 1973 to 2010 picturises complex shape of landscape.

AWMSI value is increasing from 1973 to 2010 shows the patch shapes are becoming more irregular. ENN_AM is decreasing prominently in case of cropland and urban classes because of new intermediate patches of same class are developing in the region.
Sector 2 shows of increase of numbers of cropland patches (33 to 6904), vegetation (252 to 803 ). This indicates the evolution of new patches during 1973 to 2010 resulting in land use changes in the region. There is no urban class in this region in 1973, but new rural agglomerations in 1989 due to the conversion of forest and croplands, which resulted in the largest patch in 2010. PARA_AM and AWMSI show the region is becoming more complex in terms of shape especially urban class (57.49) and ENN_AM of urban class has reduced (84.92 to $40.08 \mathrm{M}$ ) during 1989 to 2010.

Sector 3 depicts more number of patches in most land use classes except urban class. The urban class exhibit concentrated growth at Kalghatghi with new clusters. In 1973 cropland category has largest patch, but in 2010 largest patch has changed to urban category. PARA_AM shows higher values in all categories other than urban reflecting the convolution of shapes and AW_MSI explains these shapes are becoming simpler than 1989 to 2010. ENN_AM values are decreasing from 1973 to 2010 shows the intermediary patch developments with complex shapes.

In sector 4 a number of vegetation patches turns out to be more (321 to 2851) and has made the area fragmented due to cultivation from 1973 to 2010. LPI shows cropland is revolved to be larger patch from vegetation. PARA_AM shows the complexity of shape with respect to forest and AWMSI shows from 1973 to 2010 cropland is becoming simpler shape by intermediate patches development of same class.

Sector 5 has more numbers of patches with respect to crop and urban classes and number of vegetation patches are coming down, which highlight of effective forest management from 1989 to 2010 but even though largest patch belongs to cropland. PARA_AM, AWMSI shows the shape complexity for cropland and urban classes. ENN_AM shows the higher value for forest patches because of intermediate croplands, which have the influence in distance between nearest neighbour patches of same class.

Sector 6 shows higher number of forest (202), urban (1588) cropland (167) patches, clearly indicates the fragmentation and also largest patch is crop land; reason behind is the Yellapur town situated in this sector. PARA_AM shows urban, cropland is having complex shapes. Among all cropland is having more convoluted shape, which is revealed by AWMSI. Because of intensified growth in the region, which shows higher distance between the open space patches.

Sector 7 is less fragmented compared to all sectors with less number of patches except urban class. In 2010 only new urban patches are observed in the region but still cropland is the largest patch because of no intermediate patches are present. But in terms of shape AWMSI shows crop land is having more convoluted shape. ENN_AM shows high value for the open space category because of no barren areas is present nearby in the region. 


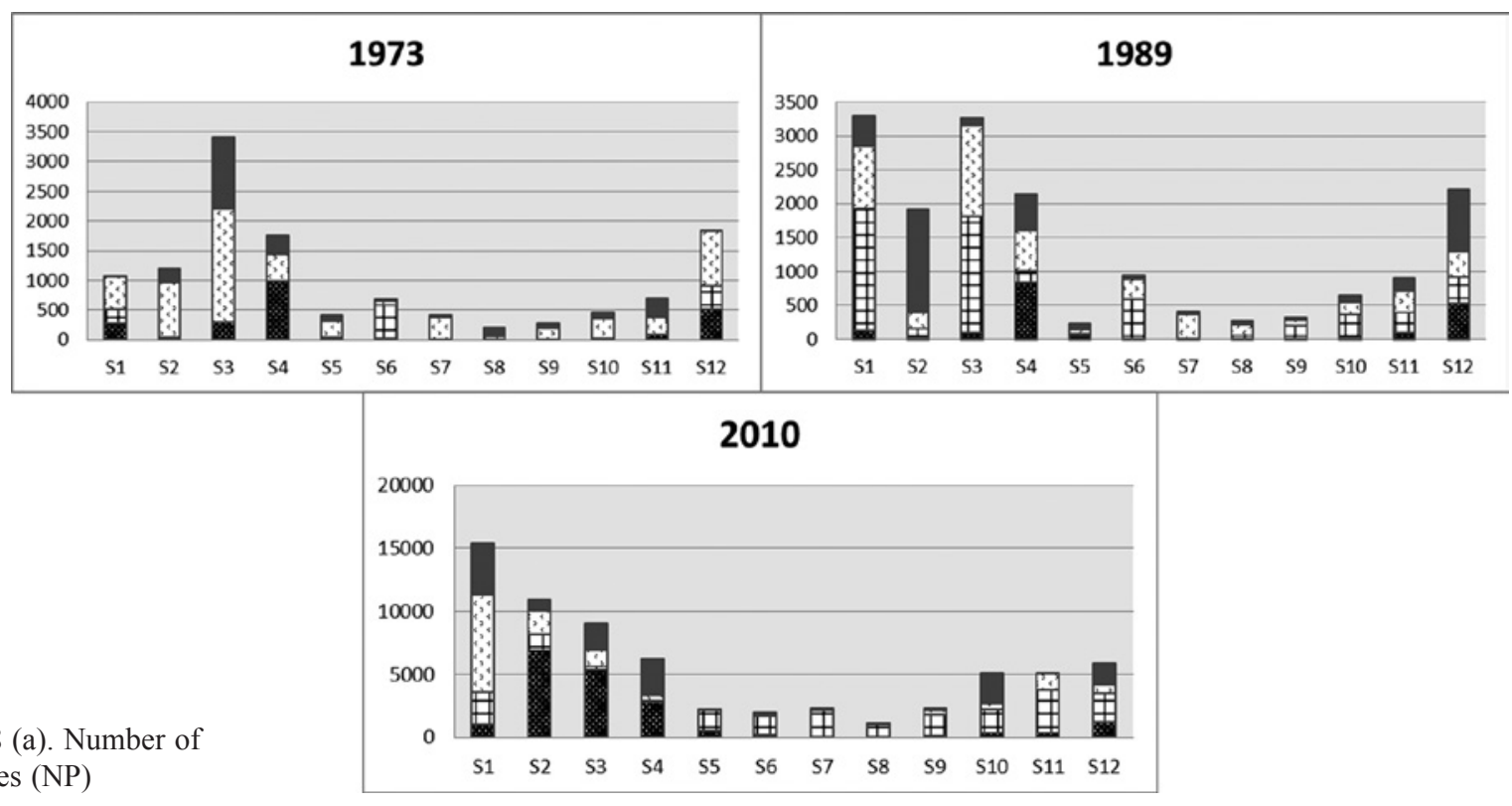

patches (NP)
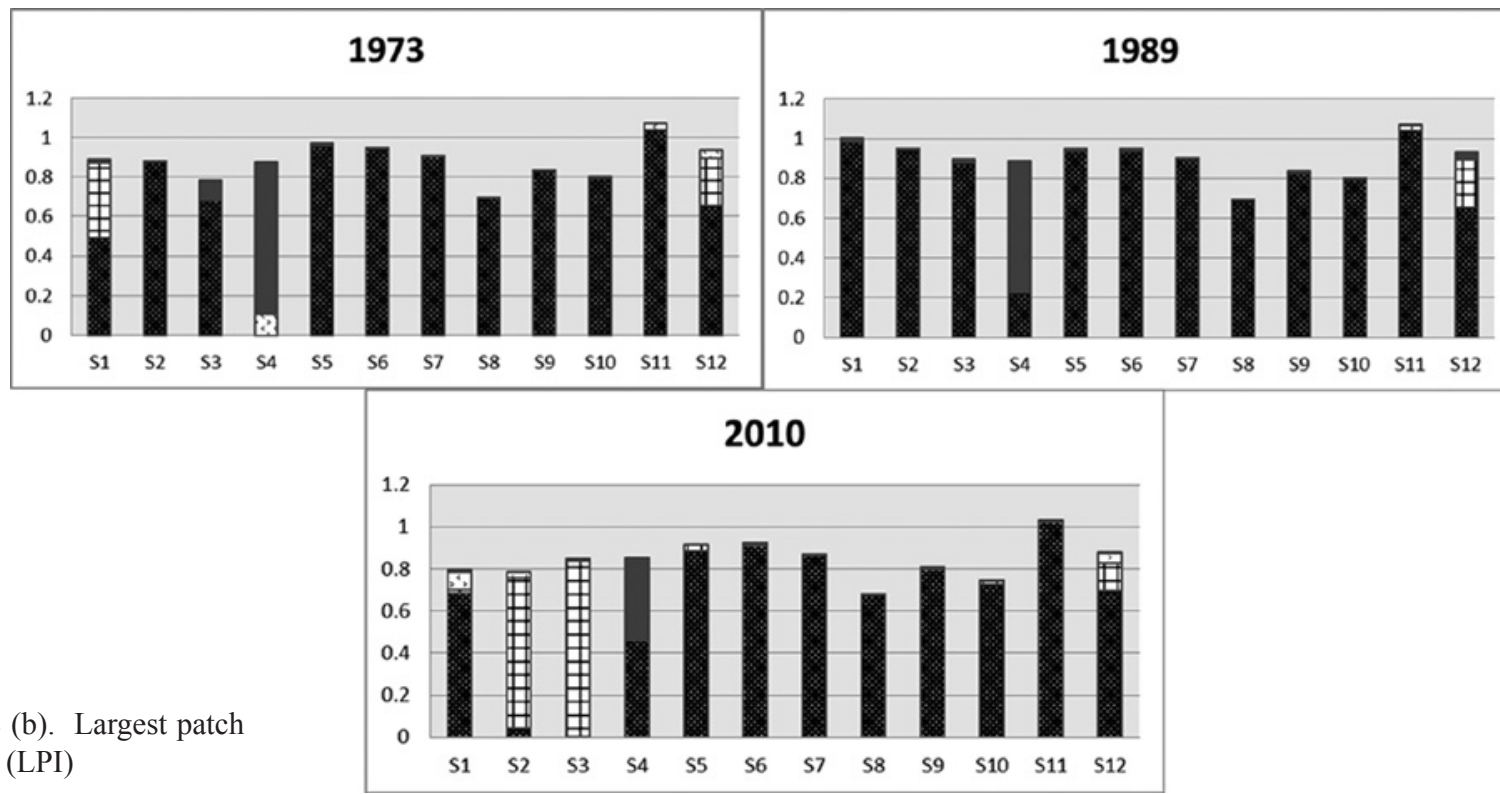

Fig. 8 (b). Largest patch index (LPI)
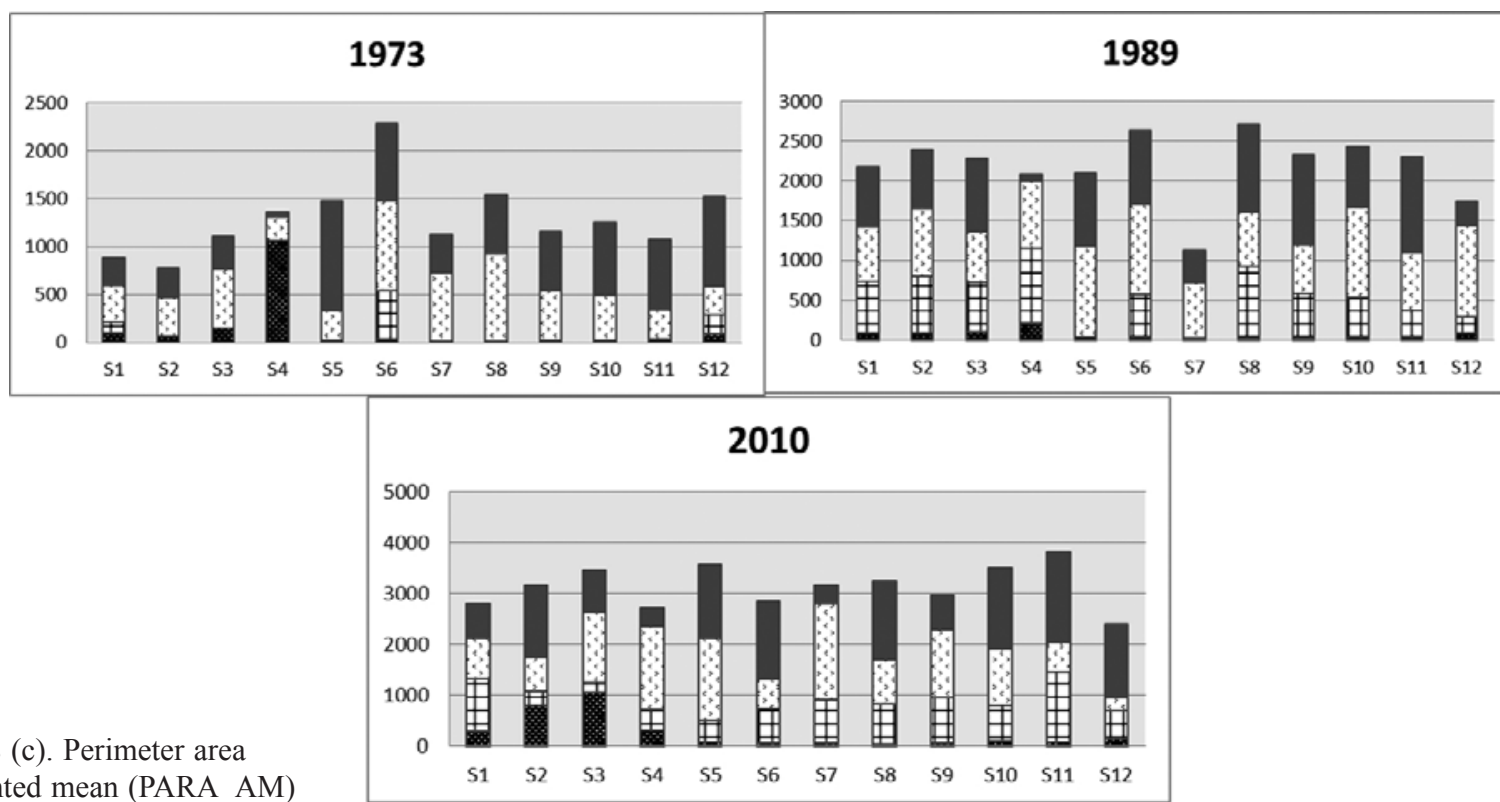

Fig. 8 (c). Perimeter area weighted mean (PARA_AM) 


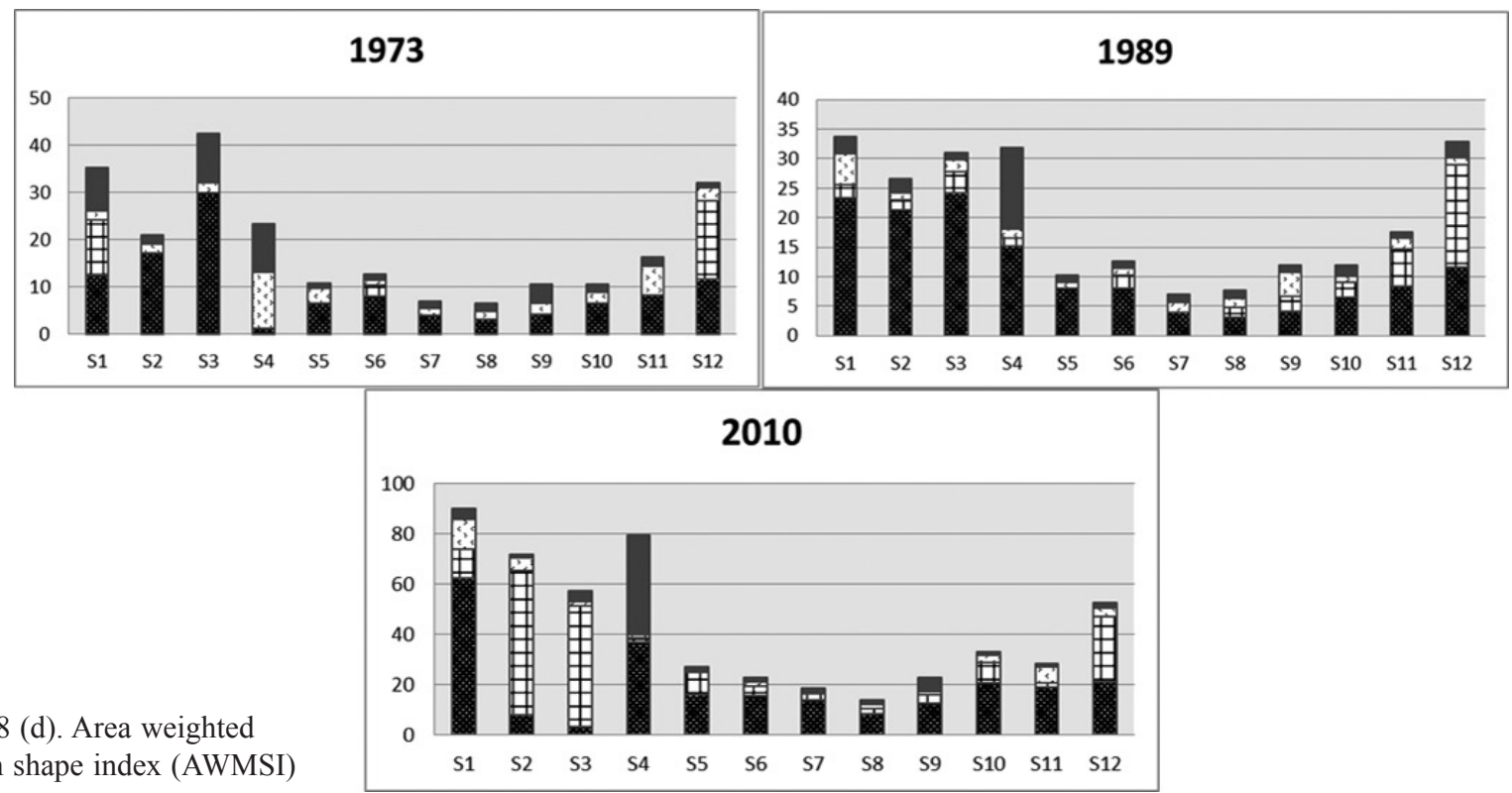

mean shape index (AWMSI)

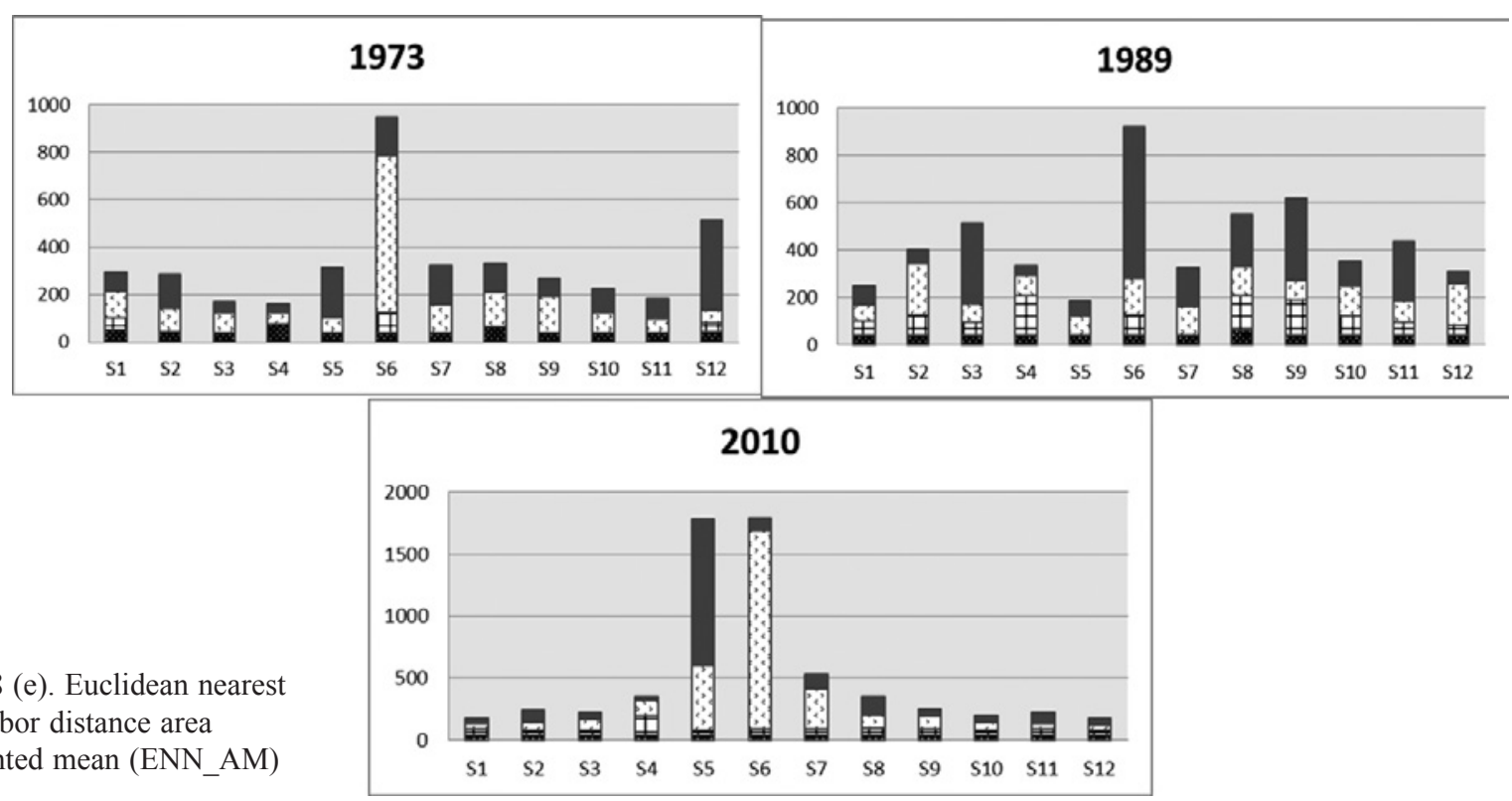

neighbor distance area

weighted mean (ENN_AM)

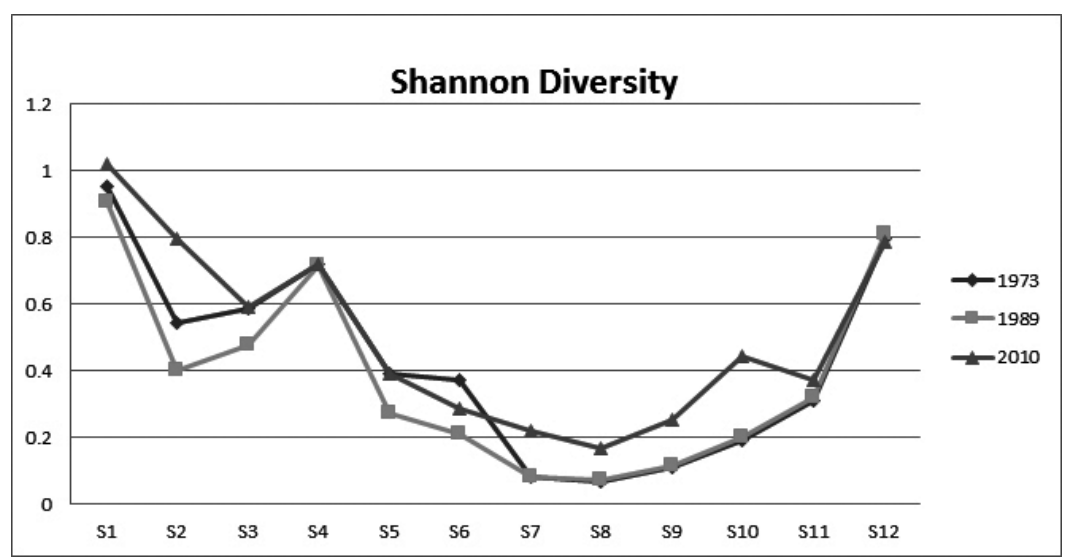

Fig. 8 (f).

Shannon's

diversity

Fig. 8. Landscape metrics ((a) through (f))

Note: X Axis - Sectors; Y Axis - Metric value. 
Sector 8 has more number of patches for urban which are isolated to each other and largest patch is cropland. PARA_AM explains all categories have shape complexity. AWMSI reveals cropland is have more convoluted shape than other. ENN_AM values came down from 1973 to 2010 due to human induced small patches.

Sector 9 is more fragmented with respect to urban and forest cover. In this sector among all classes cropland $(79.7 \%)$ is largest patch. PARA_AM has high degree of complexity in land scape shape and AWMSI gives cropland and forest cover have convoluted shapes. Forest patches have less distance and open space is filled by built-up and cropland lead to higher distance of value for open space category due to intermediate urban patches.

Sector 10 has more number of urban patches (1852) with the increase in forest fragmentation evident from the increase in patches from 106 to 2482. Largest patch is located by cropland $(72.63 \%)$. PARA_AM shows the complexity is unanimous for all the categories and AWMSI shows cropland and urban has high evolvement of shape. Decrease in ENN_AM with all patches are distributed in less distance to same patch type from 1973 to 2010 indicates of higher fragmentation.

Sector 11 shows the region with more number of patches for urban, crop, open space categories and forest are comparatively less fragmented. LPI shows the forest $(80 \%)$ is the largest patch among all other. PARA_AM shows all categories have higher degree of shape complexity. AWMSI reveals cropland has higher convoluted shape. ENN_AM shows the progression less distance between the patches of same type.

Sector 12 is the final sector covers Ankola region having higher degree of fragmentation from 1973 to 2010 in all land use classes. LPI shows cropland (69.35\%), urban $(13.5 \%)$ are dominant patches. PARA_AM picturises all the land use classes have complex shapes and AWMSI extracts urban (25.7) cropland (21.78) has elongated shapes. ENN_AM shows urban; crop classes do not have any change in the distance and forest patches have lesser distances in the progression of new patches.

Shannon's diversity index is also referred as a landscape ecological security index and a measure of the diversity is determined by both the number of different patch types and the proportional distribution of area among patch types. This index is computed by considered landscape as a whole to assess the diversity with respect to each sector from 1973 to 2010 shown in Figure 8 (f). The results shows the higher value of diversity for sector 1 , sector 4 , sector 9 , sector 10 , sector 12 because of higher fragmentation in the distribution of patches in terms of area with respect to one of land use class, especially sector 1 and 12 are experiencing development (urban) processes. Pattern process analysis is undertaken to visualise pattern, evaluate the consequences through simulation. Population density

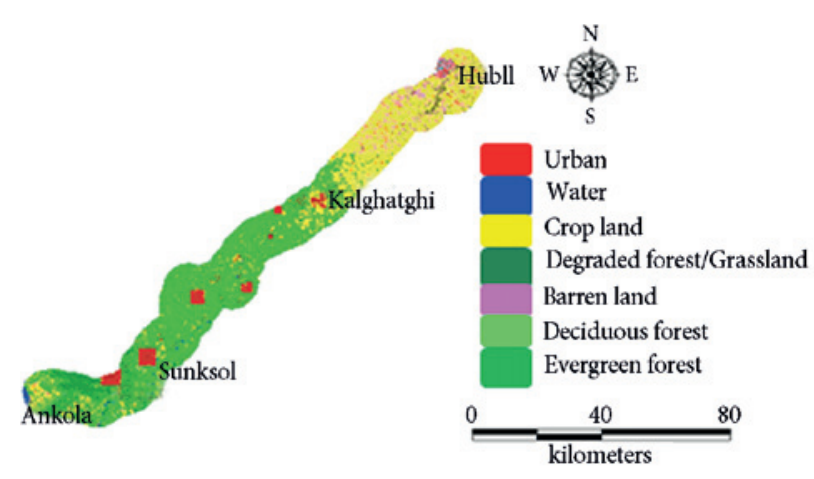

Fig. 9 (a). Base case scenario (2020)

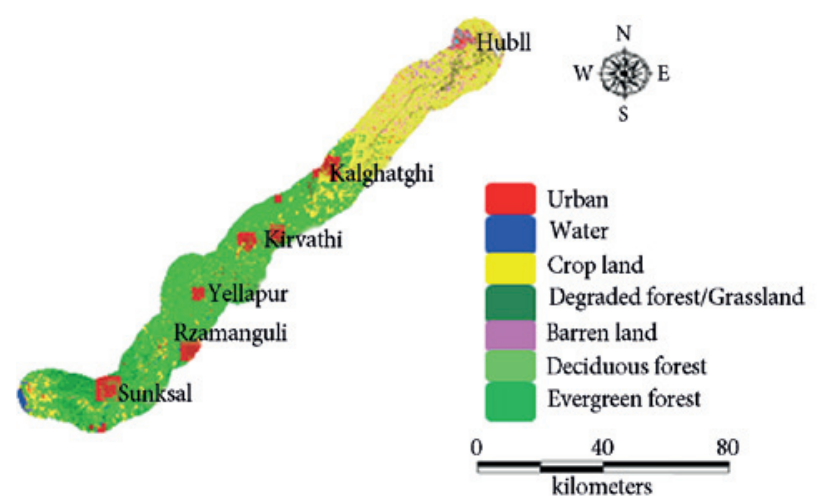

Fig. 9 (b). Scenario (2020) with the proposed developmental activities

map is generated to know the distribution of population per one square kilometer. Figure 6 shows villages between Yellapur and Ankola taluks that are sparsely populated with a population density ranging from 0 to 100 persons/ $\mathrm{km}^{2}$. This essentially helped as a base layer to project the scenario of growth pattern for 2020 .

Considering the rate of changes in the forest cover, likely changes in the region is predicted for 2020 (Fig. 9 (a), (b)) considering the business - as usual scenario and likely implementation of developmental projects in the region. Figure 9 (a) depicts the decline of forests by 11.8 percent by the Year 2020 considering the business as usual scenario. The simulation outcome given in Figure 9 (b) indicated that there would be a growth of 16.23 percent in the region consequent to land use changes with implementation of development projects like new motor ways, industries and railways. This highlight intensified urban growth for Kalghatghi, Yellapur, Ramanguli and Sunksal regions with new agglomeration and it may leads to peripheral growth with higher deforestation.

\section{Conclusion}

1) Spatio temporal dynamics analysis through the integration of multi temporal data offered an efficient way to examine forest spatial changes and fragmentation;

2) Human induced changes shows $15.64 \%$ loss in the vegetation cover from 1973 to 2010; 
3) Land use analysis shows the degradation of deciduous forest cover from $56.23 \%$ to $47.93 \%$ due to human induced changes leading to fragmentation in the region;

4) The landscape metrics analysis indicates of increase in the number of patches in the forest dominated areas that highlight the fragmentation of the vegetation cover. LPI index indicates that crop land has become dominant land use in the region. PARA_AM index shows complexity of the region in terms of shape because of alterations in the land cover;

5) These results reveal that plane region is influenced by anthropogenic activities because of urbanization. The Sahyadri interior with undulating topography coupled with the effective conservation policies show nominal land use (buildings and agriculture) changes. The coastal region is more fragmented due to over exploitation of resources due to road accessibility. Thus, where densely distributed roads are present, forests are in peril;

6) The prediction for 2020 indicates of $11.8 \%$ decline in forest cover (in the business as usual scenario) and $16.23 \%$ decline with the implementation of developmental projects and associated local land use changes;

7) This work provides a valuable spatial insight into the trends in forest change and fragmentation with conservation implications for sustainable growth. Landscape analysis with incorporation of geographical and sociological perspectives, practical and theoretical approaches will help in tackling environmental problems.

\section{Acknowledgement}

The authors are grateful to the Infrastructure Development Department (IDD), Government of Karnataka and NRDMS Division (DST), The Ministry of Science and Technology, Government of India and Indian Institute of Science for the financial and infrastructure support. The authors thank National Remote Sensing Centre, Hyderabad (http://www.nrsc.gov.in), for providing the IRS data.

\section{References}

Carvalho, F. M. V.; de Marco, P.; Ferreira, L. G. 2009. The Cerrado into-pieces: habitat fragmentation as a function of landscape use in the savannas of central Brazil, Biological Conservation 142: 1392-1403.

http://dx.doi.org/10.1016/j.biocon.2009.01.031

Freitas, S. R.; Hawbaker, T. J.; Metzger, P. J. 2010. Effects of roads, topography, and land use on forest cover dynamics in the Brazilian Atlantic Forest, Forest Ecology and Management 259: 410-417. http://dx.doi.org/10.1016/j.foreco. 2009.10 .036

Garcia-Feced, C.; Saura, S.; Elena-Rossello, R. 2011. Improving landscape connectivity in forest districts: a two-stage process for prioritizing agricultural patches for reforestation, Forest Ecology and Management 261(1): 154-161. http://dx.doi.org/10.1016/j.foreco.2010.09.047

Geri, F.; Amici, V.; Rocchini, D. 2010. Human activity impact on the heterogeneity of a Mediterranean landscape, Applied Geography 30: 370-379.

http://dx.doi.org/10.1016/j.apgeog.2009.10.006

Gustafson, E. J. 1998. Quantifying landscape spatial pattern: what is the state of the art?, Ecosystems 1: 143-156. http://dx.doi.org/10.1007/s100219900011

Hahs, A. K.; McDonnell, M. J. 2006. Selecting independent measures to quantify Melbourne's urban rural gradient, Landscape and Urban Planning 78: 435-448. http://dx.doi.org/10.1016/j.landurbplan.2005.12.005

Herold, M.; Couclelis, H.; Clarke, K. C. 2005. The role of spatial metrics in the analysis and modeling of urban land use change, Computers, Environment and Urban Systems 29: 369-399. http://dx.doi.org/10.1016/j.compenvurbsys.2003.12.001

Jixian, Z.; Yonghong, Z. 2007. Remote sensing research issues of the National Land Use Change Program of China, ISPRS Journal of Photogrammetry and Remote Sensing 62: 461472. http://dx.doi.org/10.1016/j.isprsjprs.2007.07.002

Lambin, E. F.; Geist, H. J.; Lepers, E. 2003. Dynamics of land use land cover change in tropical regions, Annual Review of Environment and Resources 28: 205-41.

http://dx.doi.org/10.1146/annurev.energy.28.050302.105459

Li, X.; Zhang, L.; Liang, C. 2010. A GIS-based buffer gradient analysis on spatiotemporal dynamics of urban expansion in Shanghai and its major satellite cities, Procedia Environmental Sciences 2: 1139-1156. $\mathrm{http} / / / \mathrm{dx}$. doi.org/10.1016/j.proenv.2010.10.123

Liu, J.; Deng, X. 2010. Progress of research methodologies on temporal and spatial process of LULC, Chinese Science Bulletin 55: 1354-1362. http://dx.doi.org/10.1007/s11434-009-0733-y

McDonald, R. 2009. Ecosystem service demand and supply along the urban-to-rural gradient, Journal of Conservation Planning 5: 1-14.

McGarigal, K.; Cushman, S. A.; Neel, M. C.; Ene, E. 2002. FRAGSTATS: spatial pattern analysis program for categorical maps [online]. Available from Internet: http://www. umass.edu/landeco/research/fragstats/fragstats.html

Mertens, B.; Sunderlin, W. D.; Ndoye, O. 2000. Impact of macroeconomic change on deforestation in South Cameroon: integration of household survey and remotely-sensed data, World Development 28(6): 983-999. http://dx.doi.org/10.1016/S0305-750X(00)00007-3

Li, M.; Zhu, Z.; Vogelmann, J. E.; Xu, D.; Wen, W.; Liu, A. 2011. Characterizing fragmentation of the collective forests in southern China from multitemporal Landsat imagery: a case study from Kecheng district of Zhejiang province, $A p$ plied Geography 31(3): 1026-1035. http://dx.doi.org/10.1016/j.apgeog.2011.02.004

Nagendra, H.; Southworth, J.; Tucker, C. 2003. Accessibility as a determinant of landscape transformation in western Honduras: linking pattern and process, Landscape Ecology 18: 141-158. http://dx.doi.org/10.1023/A:1024430026953

Nagendra, H.; Munroe, D. K.; Southworth, J. 2004. From pattern to process: landscape fragmentation and the analysis of 
land use/land cover change, Agriculture, Ecosystems \& Environment 101: 111-115.

http://dx.doi.org/10.1016/j.agee.2003.09.003

Onojeghuo, A. O.; Blackburn, G. A. 2011. Forest transition in an ecologically important region: patterns and causes for landscape dynamics in the Niger Delta, Ecological Indicators 11: 1437-1446. http://dx.doi.org/10.1016/j.ecolind.2011.03.017

Peng, J.; Wang, Y.; Zhang, Y.; Wu, J.; Li, W.; Li, Y. 2010. Evaluating the effectiveness of landscape metrics in quantifying spatial patterns, Ecological Indicators 10: 217-223. http://dx.doi.org/10.1016/j.ecolind.2009.04.017

Ramachandra, T. V.; Kumar, U. 2004. Geographic Resources Decision Support System for land use, land cover dynamics analysis, in Proceedings of the FOSS/GRASS Users Conference, 12-14 September, 2004, Bangkok, Thailand.

Ramachandra, T. V.; Kumar, U.; Diwakar, P. G.; Joshi, N. V. 2009. Land cover assessment using À Trous Wavelet fusion and K-Nearest Neighbour classification, in Proceedings of the 25th Annual In-House Symposium on Space Science and Technology, ISRO - IISc Space Technology Cell, 29-30 January, 2009, Indian Institute of Science, Bangalore, India.

Ramachandra, T. V.; Aithal, B. H.; Durgappa, D. S. 2012. Insights to urban dynamics through landscape spatial pattern analysis, International Journal of Applied Earth Observation and Geoinformation 18: 329-343. http://dx.doi.org/10.1016/j.jag.2012.03.005

Sudhira, H. S.; Ramachandra, T. V.; Jagadish, K. S. 2004. Urban sprawl: metrics, dynamics and modelling using G1S, International Journal of Applied Earth Observation and Geoinformation 5: 29-39.

http://dx.doi.org/10.1016/j.jag.2003.08.002

Volcania, A.; Karnielia, A. 2005. The use of remote sensing and GIS for spatio-temporal analysis of the physiological state of a semi-arid forest with respect to drought years, Forest Ecology and Management, 239-250.

http://dx.doi.org/10.1016/j.foreco.2005.05.063
Waring, R. H.; Coops, N. C.; Landsberg, J. 2010. Improving predictions of forest growth using the 3-PGS model with observations made by remote sensing, Forest Ecology and Management 259: 1722-1729.

http://dx.doi.org/10.1016/j.foreco.2009.05.036

Wilensky, U. 1999. NetLogo models [online]. Center for Connected Learning and Computer-Based Modeling, Northwestern University, Evanston, IL. Available from Internet: http:// ccl.northwestern.edu/netlogo/models

World Bank, World development report. 2008. Agriculture and Development. Quebecor World, United States.

Yang, X.; Ming, G.; Luo, X.; Zheng, Z. 2011. Preliminary mapping of high-resolution rural population distribution based on imagery from Google Earth: a case study in the Lake Tai basin, eastern China, Applied Geography 32(2): 221-227. http://dx.doi.org/10.1016/j.apgeog.2011.05.008

Zang, S.; Huang, X. 2006. An aggregated multivariate regression land-use model and its application to land-use change processes in the Daqing region (northeast China), Ecological Modelling 193(3-4): 503-516.

http://dx.doi.org/10.1016/j.ecolmodel.2005.08.026

Zhang, Q.; Xiao, X.; Braswell, B.; Linder, E.; Ollinger, S.; Smith, M. L.; Jenkins, J. P.; Baret, F.; Richardson, A. D.; Moore III, B.; Minocha, R. 2006. Characterization of seasonal variation of forest canopy in a temperate deciduous broadleaf forest, using daily MODIS data, Remote Sensing of Environment 105(3): 189-203. http://dx.doi.org/10.1016/j.rse.2006.06.013

Zhou, L.; Tucker, C. J.; Kaufmann, R. K.; Slayback, D.; Shabanov, N. V.; Myneni, R. B. 2001. Variation in northern vegetation activity inferred from satellite data of vegetation index during 1981 to 1999, Journal of Geophysical ResearchAtmospheres 106(17): 20069-20083. http://dx.doi.org/10.1029/2000JD000115

Zeng, H.; Wu, X. B. 2005. Utilities of edge-based metrics for studying landscape fragmentation, Computers, Environment and Urban Systems 29(2): 159-178.

http://dx.doi.org/10.1016/j.compenvurbsys.2003.09.002

T. V. RAMACHANDRA has a PhD in Energy and Environment from Indian Institute of Science. At present, he is a Coordinator of Energy and Wetlands Research Group (EWRG) and Convener of Environmental Information System (ENVIS) at the Centre for Ecological Sciences (CES), Indian Institute of Science (IISc). He has made significant contributions in the area of energy and environment. During the past ten years he has established an active school of research in the area of energy and environment. He teaches principles of Remote Sensing, Digital Image Processing and Natural Resources Management. He has published over 206 research papers in reputed peer reviewed international and national journals, 118 papers in the international and national symposiums as well as 14 books. In addition, he has delivered a number of plenary lectures at national and international conferences. He is a fellow of Institution of Engineers (India), IEE (UK), Senior Member, IEEE (USA) and many similar institutions. His research interests include wetlands, conservation, restoration and management of ecosystems, environmental management, GIS, remote sensing, regional planning and decision support systems.

Bharath SETTUR holds a Master's degree in Computer Application (MCA) and is currently working as Research Assistant at Energy and Wetlands Research Group (EWRG), CES, IISc. His research interests include landscape ecology, spatial pattern analysis, landscape modeling, open source GIS.

Bharath AITHAL is an Electrical and Electronics Engineering graduate from Bangalore University. Currently, he is pursuing his $\mathrm{PhD}$ at Indian Institute of Science. His research interests include spatial pattern analysis, urban growth modeling, natural disasters, geoinformatics, landscape modeling and urban planning, open source GIS, digital image processing. 